\title{
EXTRACTING INDIGENOUS RIAU-MALAYS' SCIENTIFIC LITERACY THROUGH Lancang Kuning FolkLORE WITH THEMATIC LEARNING IN THE PRIMARY SCHOOL CONTEXT
}

\author{
Neni Hermita $^{1)}$, Mahmud Alpusari ${ }^{2)}$, Jesi Alexander Alim ${ }^{3)}$, Elfis Suanto ${ }^{4)}$ \\ ${ }^{1)}$ Universitas Riau, Pekanbaru, Indonesia \\ E-mail: neni.hermita@lecturer.unri.ac.id \\ ${ }^{2)}$ Universitas Riau, Pekanbaru, Indonesia \\ E-mail: mahmud.alpusari@lecturer.unri.ac.id \\ ${ }^{3)}$ Universitas Riau, Pekanbaru, Indonesia \\ E-mail: jesi.alexander@lecturer.unri.ac.id \\ ${ }^{4)}$ Universitas Riau, Pekanbaru, Indonesia \\ E-mail: elfis.suanto@lecturer.unri.ac.id
}

\begin{abstract}
This research aims to extract the story or take the essence from folklore the Lancang Kuning its scientific literacy value for thematic learning in primary school. Scientific literacy is an understanding of science and its application to the needs of the community. The method used is the descriptive qualitative analysis of interviews and documentation strategies and evaluation of data. Results from this research that obtain it some value in scientific literacy in the people story Lancang Kuning text that can then be applied in teaching in primary school using thematic learning. From these results, it can be concluded that since time immemorial been their aspects of scientific literacy are taught parents to their children either through folklore or of other matters related to culture.
\end{abstract}

Keywords: Folklore of Lancang Kuning; Scientific Literacy; Thematics Learning

\section{INTRODUCTION}

Literacy attainment in the first level of learning how to deliver and engrave is essential because in this stage, offspring drive autonomously acquire actual capability on learning cultivations or arguments. This stimulating knowledge resolves visibly encouragement broods to obligate virtuous enhancement in the establishment of their impression and inscription education progression (Furrer, 2010; Skinner \& Chi, 2010; Zimmer-Gembeck, \& Skinner, 2011). Prompting the first chapters of learning how to transcribe and recite because of robust commemoration drive rush and luxury offspring in learning in what way to deliver and engrave. It is definite that in this literacy achievement stage, offspring drive prerequisite reinforcement and relief as of their setting, which takes account of parentages, educators, and upper class (Portes \& Rivas, 2011). Social environment and nature are also swaying the usefulness of literacy achievement as in the age; offspring are on the age when they show and distinguishing their setting also impacts from household education. The requirements to cultivate this literateness acquirement aim to find a pattern or theory and practice input on in what way to acquire knowledge in pre-reading and pre-writing.

In a world filled with scientific inquiries, scientific literacy becomes necessary for everyone. Every person needs to utilize science information to do options that they choose every day (Newcomb-Anjo, Barker, \& Howard, 2017; Garrett et al., 2014; Edwards, Rodenhizer-Stämpfli, \& Eckstein, 2015; Shapka \& Law, 2013; Corenblum, 2014; Basáñez et al., 2014). Everyone needs to have the ability to smartly engage in conversation and public debate on science and technology. Everyone ready to share fulfills happiness and personal from their understanding and learning of mother nature. Science literacy also becomes a lot more important in the job market. The number of jobs that 
demand people with proficient skills: learning and reasoning ability, creative thinking, decision-making and problem solving, is increasing. Understanding science and its process have a particular contribution to those skills. Other countries have invested greatly in creating workplaces that are science and technology literate. To survive in the global market, every country needs to have its people have the same capability. Every citizen in every education level that has knowledge, understanding, and ability that are scientifically literate is necessary. Students will fail to have high performance without help from proficient skilled teachers, appropriate studying time, and room to move and learning sources around them. None of this should be detached from the scientific education system. Learning with accentuation in the scientific process is regarded as a lot more educative in terms of skills such as observing, inferring, experimenting, and inquiring about which the core of science learning is. Inquiring will let students describing objects or events, asking questions, building and testing explanations with the latest scientific knowledge, and expressing their opinion to others, they will identify their assumptions with critical and logical thinking and consider alternatives. This will make students actively develop their scientific understanding and combine their knowledge with reasoning and thinking skills.

Science literacy is important because, first, scientific understanding offers personal and happiness, a benefit to share with everyone. Second, countries are faced with questions in their life that need scientific information and way of thinking to solve. These questions play a huge part in people's life, such as questions related to air, water, and forests. Scientific understanding and skills will improve student's capacity in having important and productive jobs in the future.

In several decades, the government has do so many efforts for innovating the curriculum. Suratno (2014) identified those efforts, comprehensive curriculum reformation started in the 1970s. From active learning, process and competency approach into the thematicintegrated and scientific approach.

Curriculum changes are influenced by many factors. of that, curriculum dynamics are side by side with other dynamics such as academic, industry, and social dynamics. Those dynamics became the foundation of changes in each sector. Nowadays, changes are more oriented to people with knowledge, skills, and attitudes parallel to the present dynamics. Those challenges are not easy. It can be seen from many education work achievements in Indonesian education, for example, is the result of PISA and TIMSS that measure student's ability to several levels. The lowest level knows, the middle level is applying, and the high level is reasoning, and the highest level is strong reasoning. The 2012 PISA and TIMSS show that most Indonesian students only reached the two lowest levels, which means they have low reasoning ability. Those indicators show that all this time, teachers have a hard time in strengthen learning that is oriented in critical and creative thinking. The purpose of this research is to extract the value of Lancang Kuning folklore to be an alternative to learning sources for primary students.

\section{LITERATURE REVIEW}

\section{A. Scientific Literacy}

Scientific literacy is a kind of science and its application to the necessities of society. Science literacy is very significant and this is because first, understanding science offers personal satisfaction and joy, salaries to be shared with everyone. Second, nations are faced with questions in life that need scientific information and scientific method of thinking to create decisions and interests of people who need to be learned, such as air, water and plantations. Established countries have been constructed since the ancient scientific literacy, the application of which is integrated into the learning. In the PISA, scientific literacy includes the measurements of content, process, and context.

Scientific literacy consists of cognitive as fine as motivational and value connected phases of domain-specific capabilities (Marshall, Scheppler, \& Palmisano, 2002; Millar, 2006). Permitting this, knowledge and attitudes are seen to be relevant components of scientific literacy in the framework for the Program for International Student Assessment (PISA) 2006.

PISA notifies contributing countries to the extent to which their pupils are arranged for the knowledge society at age 15. After the scientific literacy perception is defined exceeding, it is educational to appearance at the relative between science performance and scientific curiosity at a country level. First results from PISA 2006 (OECD, 2007) suggest that this is not automatically the case. Students in Finland as the best-performing country in science in PISA 2006, show strangely low attention in science, as do students in other high recital countries like the Netherlands, New Zealand, the UK and Australia. Simply in a few countries, among them, Germany, Japan and Austria, do we invention an acceptable level of curiosity in positions of the complete meaning of scientific literacy. Outcomes approximating this involve an earlier look at curiosity and its construction.

Benefits performance an important role in initiating, steering, and retaining the engagement are in specific domains and learning processes (Renninge et al., 1992; Schiefele, 2009). In learning research, awareness has been conceptualized as a phenomenon that occurs from a creature's communication with an object or certain content (Krapp, 2002). The personal lateral of this model has been glowing particularized. The investigation has concentrated on a variation of the individual characteristics of the principle, e.g. attention (Ainley, Hidi, \& Berndorff, 2002; Hidi, Renninger, \& Krapp, 2004), goals (Harackiewicz et al., 2002; Pintrich, 2002; Sansone \& Smith, 2000), or levels of learning (Alexander \& Murphy, 1998; Hoffmann, 2002; Köller, Baumert, \& Schnabel, 2001). Interests, however, are not necessarily termed when seen only from the personal lateral. The substances and areas of interest are occasionally termed as opportunity structures for the enlargement of 
interest. In most methodologies, interest is observed as existence area-specific (Häussler \& Hoffmann, 1998). Nevertheless, a much smaller investigation figure can be established on the purpose aspect of interest. The topological perception Häussler and generations assumed for the Leibniz-Institute for Science Education (IPN) study on physics interest applications on the construction of the area (Häussler, 1987). In their topological typical of behavior concentration, they separate detailed subjects, frameworks in which the subjects are characterized and actions in which the different can participate. Students are scientifically antagonized with subjects, submission capacities and actions connected to physics.

\section{B. Folklore of Melayu Riau (Lancang Kuning)}

Malay ethnic groups are tribes with a tradition of strong family education (Isjoni, 2015a; Isjoni, 2015b; Effendy, 2006; Koentjaraningrat, 1970). All education is intended to establish noble character because the Malays that human life would be beneficial to other humans. One of the teachings manners Malay important to be learned is the moral character of the child's parent (Isjoni, 2015a; Santoso, 1986).

Malay ancestors were not only concerned with what should be obeyed by the only child to her parents. Moreover, parents also appeared to be had the manners to their children. The character of parents to children is a set of obligations should parents do to their children so that children can develop well in the traditions of the Malay (Isjoni, 2015a; Santoso, 1986; Purna, 1993).

Attention, affection, giving freedom to children, as well as a good education, are some of the manners that should be owned by Malay parents to their children. Character is mandatory for parents should not wash its hands of the development and growth of children, both physically and mentally. The Malays assume the manners of a parent to this child as a parent on the child's debt (Effendy, 2006).

In general, the characteristics of the Malays can be described as follows: (a) in interacting with members of different ethnic communities tend to interact peacefully and try to avoid conflict. (b) Because of mind and language Malay smooth, then in passing on the things that feared could create misunderstandings and misconceptions, the Malays in an opinion or issue often uses rhymes, poems, or parables. (c) The Malays do not want to stand out, especially on issues of wealth and income. (d) The Malays in general are people who are very sensitive and delicate feelings (sentimental). This is reflected in the song's typical Malay-blue feeling. (e) The Malays in general are very introvert (closed) so the association with people from other ethnic groups tends to require a lengthy process. (f) On the whole attitude of the Malays are very tolerant and try to establish peaceful interaction with other communities. $(\mathrm{g})$ Although the attitude of people wilts tolerant and peaceloving, when pride is humbled, they may rebel (Isjoni, 2015a; Koentjaraningrat, 2007).

Excellence character Malay of Riau community in the past, generally transformed through education in the family. Parents have started educating their children in the womb. A wife who is pregnant is given taboos, such as not allowed to do things that are not good, such as anger, berating, lying, original way, dreamy, lazy, sleep, immodest dress, eating, and drinking which is not kosher. Husband and wife are also prohibited from slaughtering animals, sad, tied a cloth towel or the like on the neck, eating cow leather, stingray leather, sour eggplant, and reborn. When out evenings, should bring as nails, machetes and the like (metal).

After the child is born, the male is whispered Adzan while the female has whispered iqamat. During the swing, children are always put to sleep by singing "Lailahaillallah". When the child can communicate with parents, children began to be educated with various restrictions, such as not allowed to eat the Cane at sunset, not allowed to sleep at the time of maghrib, should not sit or stand in front of the patio doors, should not sew at night, not allowed to sleep snoring, should not be outside the house at the time of Maghrib prayer, should not cut nails or hair at night, and so forth.

Moreover, parents also to educate their children to be Polite in speech and behavior towards older, including his parents. Children are also taught through folktales such as "Batang Tuaka", "Mambang Linau", "Putri Kaca Mayang", "Putri Pandan Berduri", "Lancang Kuning", "Batu Belah Batu Bertangkup", etc. These stories contain the value of education and high moral and can serve as role models for children Malays (Melayu Riau).

The Malays of Riau have always craved their children to be 'people', in the sense of a successful man, both physically and mentally. Therefore, they are very concerned about the education of children from an early age. Various ways they use as a medium for conveying fatherly religious teachings and customs, with the hope, religious teachings and customs are embedded deep in the hearts of their children. One of the media used the parents is a Dodoi song. If we go for a walk to the Malay villages, still often heard his mother humming lull in a hammock or sling. Dodoi lyrics of the songs usually contain moral teachings and advice. Then, through the Dodoi humming a song, a mother can do two things at once: putting the child, and at the same time teach their children moral values and religion.

\section{Thematic Learning}

The integrated curriculum looked at the important relationship between the relational learned in schools with in everyday life. This is because such a curriculum approach that emphasizes facilitating students to undertake various connections with the environment while they learn at school.

There are various views related to the nature of the integration of the curriculum. Nothing is integrated with the context within a discipline only, integrated within the scope of inter-disciplinary, integrated within the students and integrated into the network of interactions between students. Based on these criteria (Fogarty, 1991; Kahveci \& Atalay, 2015; Yvonne, 2015; Anderson, 2013) identified ten integrated curriculum model.

Formerly Jacobs (1989) categorized five stages in an integrated curriculum which kinds between discipline-based curriculum and thematic curriculum that reflects the degree 
of its integration. The fifth is a parallel discipline, multidisciplinary, interdisciplinary, integrated (thematic), and complete integration.

The investigation reviewed for this shot shows no detrimental effects on knowledge when students are complicated in an integrated curriculum. The zones of integration included: (1) art, mathematics, and reading; (2) writing across the curriculum; (3) history, science, and mathematics; (4) history and literature; (5) integrated humanities; (6) health and reading; (7) areas of mathematics; (8) social studies, health, and the arts; (9) physical education, the arts, health, and literature; and (10) science, social studies, health, and the arts (Aschbacher, 1991; Edgerton, 1990; Greene, 1991; MacIver, 1990; Shoemaker, 1989; Vars, 1965; Vye, 1990; Williams, 1991).

There is an insignificant frame of an investigation linked to the effect of an integrated curriculum on student attitudes. MacIver (1990) created that integrated package students established group essence and developed their attitudes and drudgery ways. This was recognized, in part, to the fact that teachers encountered in teams and were able to rapidly recognize and deal with a student is problematic. Vars (1965) also reported that stimulus for learning is increased when students work on "real" complications a public component in integrated programs. When students are actively involved in planning their learning and in making choices, they are more motivated, dropping performance difficulties. Jacobs (1989) also reported that an integrated curriculum is connected with better student self- direction, higher appearance, higher stages of lesson completion, and better attitudes near the school. Students are involved in their knowledge as they make networks through disciplines and with the world outside the classroom.

Students are not the only ones who return constructively to the learning experiences that are part of an integrated curriculum. In the education of an integrated mathematics curriculum, Edgerton (1990) established that after one year 83 percent of the teachers elaborate chosen to continue with the integrated package rather than return to the traditional curriculum. MacIver (1990) created that teachers grow the social support of working composed and feel that they can teach more effectively when they integrate across focuses and progressions. They learn new benefits and teaching techniques that regenerate their teaching.

\section{METHODOLOGY}

The method that has been utilized in this research is a case study. Data was collected related to the folklore of Lancang Kuning by utilizing a case study in the Riau-Malay context. The number of participants in this study consisted of two people, namely Mr. Abdul and Mrs. Syarifah. Meanwhile, the case study technique obtains disparagement in the relation of its dearth of heftiness as a study device, crafting the design of case studies is of paramount standing. Investigators container accept whichever a sole circumstance or numerous situation project contingent on the problem in the inquiry. In suitcases anywhere nearby remain no additional suitcases existing aimed at repetition; the investigator can accept the solitary field study (Zainal, 2007). For illustration, a Riau-Malay people want to extract the value of Lancang Kuning folklore from the indigenous people who he/she is being the head of tribes. Though, the disadvantage of a sole-situation project is its incapability to deliver a simplifying assumption, in specific after the proceedings are infrequent. The unique technique of overwhelming this is by triangulating the research with additional approaches in terms of settling the legitimacy of the procedure. In this study, we have already committed to utilizing the single-case case study in analyzing the value.

\section{A. Data Sources}

Data as of this study are the main data in the practice of tale/difference of opinion occupied as of snitch or spoken speech as of inhabitants in the study setting. Meanwhile, the subordinate figures occupied are recorded underneath.

\section{B. Research Location}

Lancang Kuning folklore is one of the spoken literature from Kabupaten Bengkalis, Riau. This story is very famous for Riau-Malay to be inspired by indigenous people to gain value.

\section{Source of Information}

People chosen as main informants are the elders and prominent figure between locals who knows the story of Lancang Kuning.

\section{Other Sources}

Folklore "Lancang Kuning" Text is the main story of Lancang Kuning folklore in the Riau-Malay context. The resume of the story describes as follows:

Lancang Kuning is folklore from Kabupaten Bengkalis, precisely, Kecaman Bukit Batu. Lancang Kuning is derived from the word "Lancang" (the ship of the kingdom) and "Kuning" (yellow, the color of the kingdom). Lancang Kuning is the greatest ship used by Kings of Melayu Riau. The legends and the folklores take that title because the story revolves around events that happened between the royals. As usual, the story is rarely completely told. Moreover for this story, there are only a few written texts. To make this story complete, the verbal explanation from elders in the area, Bukit Batu itself, Selat Panjang, Bengkalis and others especially from Riau's cultural intellect, Mr. Tenas Effendi are taken.

Once upon a time, Datuk Laksamana, the leader of Bukit Batu in Bengkalis, Riau, calls his commodores, commodore Umar, and commodore Hasan. They are given orders to get rid of Pirates in Tanjung Jati. These pirates are often creating chaos in Senggoro, where fishermen often fished. Commodore Umar then left hesitantly, as he is hesitant to leave his beautiful wife, Zubaidah. While Commodore Hasan doesn't leave because of the news of the pirates there is Hasan's strategy so that Commodore Umar will be away from his wife and Datuk Laksamana.

During commodore Umar's leave, Commodore Hasan silently seduces Zubaidah to leave his husband and promise 
her a better future but Zubaidah stands firm in her choice to be faithful to his This situation anger Commodore Hasan even more and get him more brutal. Commodore Hasan finds a way to kill Zubaidah. In time with the launch of Lancang Kuning to the sea, the ship doesn't move and stay still. Commodore Hasan then took Zubaidah as a sacrifice in the dock. The ship then launched to the sea with Zubaidah ended her life under the Lancang.

Not long after Zubaidah's death, Commodore Umar comes home from Tanjung Jati and told defamation by Commodore Hasan. He was told that Datuk Laksaman was the one who killed Zubaidah by using her as a sacrifice for the Lancang. Commodore Umar believes him and he kills Datuk Laksamana without further thinking. As his last words, Datuk Laksamana curses Commodore Umar, that if Commodore Umar passes Tanjung Jati, he will drown along with his ship

Commodore Umar then realizes that it is a lie. The fight with Commodore Hasan then occurred with Commodore Hasan died on Commodore Umar's keris as the end.

Commodore Umar then goes to complete Datuk Laksamana's curse. He sails to Tanjung Jati and drowns. Since then, Bengkalis Island is known as a desolate island compared to other Islands in Riau, even until today.

\section{E. Techniques Used to Attain Data}

Data from this research are attained by:

a) Interview; Researchers have ever been interviewed informants or sources to attain data about Lancang Kuning folklore.

b) Documenting; Researchers took pictures (photo-taking) of illustration or objects related to the folklore that later can be used as evidence of the research.

c) Data evaluating; examining data taken from the main informant and used additional informants around the area of the research.

\section{F. Techniques Processing Data}

After the data is attained, the next step is processing the data using techniques below:

1. Translation

The written form of Lancang Kuning folklore translated into Bahasa Indonesia. The translating process is translating the content of the text as Lancang Kuning folklore is in a form of prose.

2. Analysis

The translation based on interviews and observation then analyzed or understood according to the problem decided.

An easy way to comply with the conference paper formatting requirements is to use this document as a template and simply type your text into it.

\section{RESULTS AND DISCUSSION}

The content of the text (book published by Culture and Tourism Department of Kabupaten Bengkalis, Riau), Lancang Kuning folklore tells about the glory of Bukit Batu Bengkalis led by Datuk Laksamana Raja Di Laut, which becomes a legend of the sea because of all of the evils in the sea surrender to him. These evils are pirates that rob harvested crop and trades, also attacks from other countries Datuk Laksamana has two commodores, one of them is his daughter's (Zubaidah) husband, Commodore Umar. Commodore Umar is Datuk Laksamana's right hand because all his jobs are done greatly. This emerges jealousy from his partner, Commodore Hasan. This jealousy will then later causes the fall and decline of Bukit Batu.

Lancang Kuning Folklore can be Used as a relevant topic in thematic Learning in elementary schools. For example in the field of Mathematics, the student can calculate the area of a triangle on the sail of the Lancang Kuning Figure; in the field of science, it can be used as an application for lunar eclipse material, reproductive material, etc; in the field of social science, it can study the material of a country's leader; while the language field can hone student literacy skills. So that any type of folklore that exists in the area can be preserved by integrating into learning in elementary schools.

The Content of The Story according to the prominent figure in society:

1. Someone regarded as a figure in education

2. Prominent Figure in Society (The Chief of Datuk Laksamana Area's Youth)

Historical tourism Datuk Laksaman Raja Di Laut Sukajadi Village, Bukit Batu Sub-District, Bengkalis District, Riau. The village that is also called Bukit Batu Darat village is similar to other villages. This village has a history that must be considered in historical records as a historical record of Melayu culture in Indonesia.

Sukajadi Village is the agriculture of cultivation. Different from Bukit Batu Laut village, beside Bukit Batu Darat village, the village has 80 family lives there, give or take a few. Most of them are mothers and daughters, weaving while the men are fishing.

Datuk Laksmana is a title from the Siak Kingdom for the keeper of the seashore of Malaka strait. Datuk Encik Ibrahim is called the first, titled Datuk Laksamana Raja Di Laut I from the year 1767 to 1807 .

There are four Datuk that led Bukit Batu. The three successors are Datuk Khamis, Datuk Abdullah Shaleh, and Datuk Ali Akbar. They presumed the title Datuk Laksamana II to IV.

Allegedly, Datuk Laksamana Raja Di Laut becomes the famous legend of the sea. All of the evils in the sea such as pirates and attacks from abroad, all surrender to him.

Science Literacy can be found in Lancang Kuning text are below:

Case 1

"It is not good to cry at the night, Baidah. Calm your heart and believe in Kanda. Didn't Mak Dukun said when you are pregnant, don't get sad often?"

The bolded underlined words above have this meaning: over-crying often happens during pregnancy. This could be happening because the hormones are at their peak.

\section{Hormones during Pregnancy and their roles}

Three hormones significantly increasing during pregnancy: estrogen (the most dominant one, produced by 
Ovum); Progesterone (this hormone is responsible to balance the estrogen, produced by Corpus Loteum at the beginning of the pregnancy and in the placenta during the end of pregnancy). Last, gonadotropin, also known as hCG, is produced by the placenta. The hormone changes level, therefore changing neurotransmitter, nerves that give the signal to the brain and regulate mood.

\section{The Cause of the Mood Swings}

Pregnancy, with our without plans will give stress as a side effect for the mothers, this relates to their emotion. Depression during pregnancy will increase the risk of postpartum, with $25 \%$ postpartum started during the pregnancy. Mood swings happen quickly and able to evoke bipolar disorder, a psychological disease with extreme mood swings takes form in depression and mania (Bensa in Zainal, 2007).

Based on the first case, it can be analyzed that woman who is pregnant is not allowed to be sad. It means that she is not allowed to cry lots when she is pregnant because her hormone is at the highest level.

There are three hormones that they will increase significantly when she is being pregnancy, that is, estrogen (the hormone is the most dominant than others which are produced by ovum); progesterone (the hormone which has the function to stabilize the estrogen, it is produced in the corpus luteum when she is in the earlier pregnancy and placenta is at the end of pregnancy). Finally, gonadotropin is well-known as hCG, which is produced by the placenta. The changing level of the hormone can change the neurotransmitter, as a neuron that is a signal source to the brain for fixing the mood. Regarding the research in 1999 in the journal of "Psychoneuroendocrinology" is founded that hormone of progesterone increase sharply when she is pregnant at the end of her pregnancy period which is connected to her mood. You will happen the changing of the mood as the hormone changing that occurred in the sixth and tenth of the third of pregnancy period. Then, in the trimester is an American Pregnancy Association.

A mount of 10-15 percent of woman who has experience is in depression while pregnancy period. Depression in the pregnancy period will increase the risk of the postpartum phase, as a case of postpartum in about 25 percent that usually starts in the pregnancy period. The mood-changing that very fast can trigger bipolar disorder disease that is a psychological disease. It happens that is note as a moodchanging (deep- feeling) that is extreme, that is depression phase.

\section{Case 2}

"On his way home, Commodore Umar immediately looks around for that list. He doesn't realize that he and his soldiers have been gone for a month. During the full moon, far away there, all the people and leaders of Bukit Batu Kingdom stand in the seashore to see the launch of Lancang Kuning”.

In the underlined and bolded words, in science education, full-moon is the same as high tide. This meaning is high correlate with the scientific phenomenon which has several functions in daily life such as tide for correlate with the moon.

\section{Tide Types}

Spring Tide happens when the earth, moon, and sun are in one straight line. At that time, the tide will be high while the low being really low. This tide happens during the full moon and the new moon.

Neap tide happens when the earth, month and sun create a perpendicular angle. During neap type, the high tide will be low while the low tide will be high. This tide happens during.

\section{CONCLUSIONS}

In the literacy context, the Lancang Kuning folklore is the main idea for inspiring the Riau-Malay people to implement the good value in their lives, for instance: in the story of the tide content, we can gain the value that the woman is not a burden for being the sacrifice for the sailor to gain the benefit. It is not a good idea for overcoming the sailors' journey problem. Thus, we can obtain the good value that the sacrifice of a pregnant woman is not true and we should have obtained the good value is the sacrifice of woman are very important. If these story values are understood by the students in their classroom context especially in the primary education level, that is, the good values which are lots in the folklore story to be learned and implemented in their daily lives.

\section{ACKNOWLEDGMENT}

The author would like to thank the prominent figure of Melayu Riau society, and the Library of Bengkalis District that has been facilitating the researcher to find the folklore of Lancang Kuning.

\section{REFERENCES}

Ainley, M., Hidi, S., \& Berndorff, D. (2002). Interest, learning, and the psychological processes that mediate their relationship. Journal of Educational Psychology, 94(3), 545-561.

Alexander, P., \& Murphy, P. (1998). Profiling the differences in students' knowledge, interest, and strategic processing. Journal of Educational Psychology, 90, 435-447.

Anderson, D.M. (2013). Overarching Goals, Values, and Assumptions of Integrated Curriculum Design, Integrated curriculum, core curriculum conceptual and theoretical foundations for integrated curriculum design. https://www.nrpa.org/globalassets/journals/schole/ 2013/schole-volume-28-number-1-pp-1-10.pdf.

Aschbacher, P. (1991). Humanitas: A Thematic Curriculum. Educational Leadership, 49(2), 16-19.

Basáñez T., Warren M.T., Crano W.D. et al. (2014). Perceptions of Intragroup Rejection and Coping Strategies: Malleable Factors Affecting Hispanic 
Adolescents' Emotional and Academic Outcomes. Journal Youth Adolescence, 43(8), 1266-1280.

Corenblum, B. (2014). Development of Racial-Ethnic Identity Among First Nation Children. Journal of Youth Adolescence, 43(3), 356-374.

Edgerton, R. (1990). Survey Feedback from Secondary School Teachers that are Finishing their First Year Teaching from an Integrated Mathematics Curriculum. Washington, DC, (ED 328 419).

Edwards, K. M., Rodenhizer-Stämpfli, K.A. \& Eckstein, R.P. (2015). Bystander Action in Situations of Dating and Sexual Aggression: A Mixed Methodological Study of High School Youth, Journal of Youth and Adolescence, 44(12), 23212336.

Effendy, T. (2006). Tunjuk Ajar Melayu. Yogyakarta: Adicita Karya Nusa.

Fogarty, R. (1991). Ten Ways to Integrate Curriculum. Educational Leadership, 49(2), 61-65.

Furrer, C.J. (2010). Capturing the friendship group context: Friendship group engagement vs. disaffection, Journal of Adolescence, 33, 853-867.

Garrett, M.T, Parrish M., Williams C. et al. (2014). Invited Commentary: Fostering Resilience Among Native American Youth Through Therapeutic Intervention, Journal Youth Adolescence, 43(3), 470-490.

Greene, L. (1991). Science-Centered Curriculum in Elementary School. Educational Leadership, 49(2), 48-51.

Harackiewicz, J.M., Barron, K.E., Tauer, J.M., \& Elliot, A.J. (2002). Predicting success in college: A longitudinal study of achievement--goals and ability measures as predictors of interest and performance from freshman year through graduation.

Häussler, P. (1987). Measuring students' interest in physics-Design and results of a cross-sectional study in the Federal Republic of Germany. International Journal of Science Education, 9, 79-92.

Häussler, P., \& Hoffmann, L. (1998). Qualitative differences in students' interest in physics and the dependence on gender and age. In L. Interest and Learning (pp. 280-289). Kiel, Germany: IPN.

Hidi, S., Renninger, K. A., \& Krapp, A. (2004). Interest, a motivational variable that combines affective and cognitive functioning. In D. Y. Dai \& R. J. Sternberg (Eds.), Motivation, emotion, and cognition (pp. 98-118). Hillsdale, NJ: Lawrence Erlbaum.

Hoffmann, L. (2002). Promoting girls' interest and achievement in physics classes for beginners. Learning and Instruction, 12(4), 447-466.

Isjoni. (2015a). Mengenal Kearifan Lokal Pada Masyarakat Melayu. Pekanbaru: Cendikia Insani.

Isjoni. (2015b). Mengenal Cerita Rakyat Melayu Riau. Pekanbaru: Cendikia Insani.
Jacobs, H. H. (1989). Interdisciplinary Curriculum: Design and Implementation. Alexandria. VA: Association for supervision and Curriculum Development.

Kahveci, N.G., \& Atalay, Ö. (2015). Use of Integrated Curriculum Model (ICM) in Social Studies: Gifted and Talented Students' Conceptions. Eurasian Journal of Educational Research, 59, 91-112

Koentjaraningrat. (1970). Manusia dan Kebudayaan Indonesia. Djakarta: Djambatan.

Koentjaraningrat. (2007). Lahirnya Konsesi Asimilasi. Jakarta: Penerbit Yayasan Tunas Bangsa.

Köller, O., Baumert, J., \& Schnabel, K. (2001). Does interest matter? The relationship between academic interest and achievement in mathematics. Journal for Research in Mathematics Education, 32, 448470 .

Krapp. (2002). A. Structural and dynamic aspects of interest development: Theoretical considerations from an ontogenetic perspective. Learning and Instruction, 12(4), 383-409.

MacIver, D. (1990). Meeting the Need of Young Adolescents: Advisory Groups, Interdisciplinary Teaching Teams, and School Transition Programs. Phi Delta Kappan 71/6: 458-465.

Marshall, S., Scheppler, J., \& Palmisano, M. (Eds.). (2002). Science literacy for the 21st century. Amherst, MA: Prometheus.

Millar, R. (2006). Twenty-first-century science: Insights from the design and implementation of a scientific literacy approach in school science. International Journal of Science Education, 28(13),1499-1521.

Newcomb-Anjo, S. E., Barker, E.T. \& Howard, A.L. (2017). A Person-Centered Analysis of Risk Factors that Compromise Wellbeing in Emerging Adulthood, Journal Youth Adolescence, 46(4), 867-883.

Organization for Economic Co-operation and Development. (2007). PISA 2006: Science competencies for tomorrow's world--Volume II: Data. Paris: OECD.

Pintrich, P. R., \& Zusho, A. (2002). The development of academic self-regulation: The role of cognitive and motivational factors. In A. Wigfield \& J. S: Eccles (Eds.), Development of achievement motivation (pp. 249-284). San Diego, CA: Academic Press. Hillsdale, NJ: Erlbaum.

Portes, A. \& Rivas. (2011). The Adaptation of Migrant Children. The Future of Children, 21(1), 219.

Purna, M. (1993). Nilai Budi Pekerti dalam Pantun Melayu. Jakarta: Departemen Pendidikan dan Kebudayaan. Direktorat Sejarah dan Nilai Tradisional.

Sansone, C. \& Smith, J. L. (2000). The 'how' of goal pursuit: Interest and self-regulation. Psychological Inquiry, 11(4), 306-309.

Santoso, B.S. (1986). Masyarakat Melayu dan Kebudayaannya. Riau: Pemda.

Schiefele, U. (2009). Situational and Individual Interest. In K. A. Wentzel \& A. Wigfield (Eds.), Handbook of motivation at school New York: Routledge. 
Shapka, J.D. \& Law, D.M. (2013). Does One Size Fit All? Ethnic Differences in Parenting Behaviors and Motivations for Adolescent Engagement in Cyberbullying, Journal of Youth and Adolescence, 42(5), 723-738.

Shoemaker, B. (1989). Integrative Education: A Curriculum for the Twenty-First Century. Oregon School Study Council 33/2.

Skinner, E.A., \& Chi, U. (2010). The Learning-Gardens Educational Assessment Group. Intrinsic motivation and engagement as "active ingredients" in garden-based education: Examining models and measures derived from self-determination theory. Journal of Environmental Education, 43, 16-36.

Suratno, T. (2014). Education system in Indonesia at a time of significant changes. Paper to be presented at International Conference Education in Asia in 2014: What Global Issue. Centre International d'Etudes Pedagogiques (CIEP), Sevres, France 1214 June 2014.

Vars, G. (1965). A Bibliography of Research on the Effectiveness of Block-Time Programs. Ithica, NY: Junior High School Project, Cornell University, 1965 .

Vye, N. (1990). The Effects of Anchored Instruction for Teaching Social Studies: Enhancing Comprehension of Setting Information. Paper presented at the Annual Meeting of the American Educational Research Association, Boston, MA. (ED 317 984) April 1990.

Williams, D. (1991). A Naturalistic Study of Unified Studies: A Holistic High School Program. Paper presented at the Annual Meeting of the American Educational Research Association, Chicago, IL. (ED 333 552) April 1991.

Yvonne, J.J. (2015). A "New" Thematic, Integrated Curriculum for Primary Schools of Trinidad and Tobago: A Paradigm Shift, International Journal of Higher Education 4(3). Published by Sciedu Press 172 ISSN 1927-6044 E-ISSN 1927-6052.

Zainal, Z. (2007). Case study as a research method. Jurnal Kemanusiaan, 9.

Zimmer-Gembeck, M.J., \& Skinner, E.A. (2011). The development of coping across childhood and adolescence: An integrative review and critique of research, International Journal of Behavioral Development, 35, 1-17. 